\title{
TIME TO LUNG VOLUME STABILITY AFTER PRESSURE CHANGE DURING HIGH-FREQUENCY OSCILLATORY VENTILATION
}

David G Tingay $\mathrm{PhD}^{1,2,3}$, Nicholas Kiraly FRACP ${ }^{1}$, John F Mills $\mathrm{PhD}^{1,2}$, Peter A Dargaville $\mathrm{MD}^{1,4}$

${ }^{1}$ Neonatal Research, Murdoch Children's Research Institute, Parkville, Australia

${ }^{2}$ Department of Neonatology, Royal Children's Hospital, Parkville, Australia

${ }^{3}$ Department of Paediatrics, University of Melbourne, Melbourne, Australia

${ }^{4}$ Department of Paediatrics, Royal Hobart Hospital and University of Tasmania, Hobart, Australia

\section{Corresponding Author:}

A/Prof David Tingay MBBS FRACP PhD

Neonatal Research

Murdoch Children's Research Institute

50 Flemington Rd.

Parkville 3052 Victoria

Australia

+61393454023

+61393455067 (fax)

david.tingay@rch.org.au

Word Count: 2540 words

Short Running Title: Time to stable lung volume during HFOV

Key Words: High frequency oscillatory ventilation; infant; mechanical ventilation; lung 
medRxiv preprint doi: https://doi.org/10.1101/2021.01.28.21250723; this version posted February 1, 2021. The copyright holder for this preprint (which was not certified by peer review) is the author/funder, who has granted medRxiv a license to display the preprint in It is made available under a CC-BY-NC-ND 4.0 International license

Conflicts of Interest and Source of Funding: DGT was supported by a National Health and Medical Research Council Clinical Research Fellowship (Grant ID 491286 and 1053889). DGT, NK and JFM are supported by the Victorian Government Operational Infrastructure Support Program. None of the authors have any conflict of interest to disclose.

Author Contributions: DGT, PAD, JFM developed the concept and designed the study. DGT enrolled and studied all infants. NK developed the mathematical models used in the study. NK, DGT and PAD were involved in data analysis and interpretation. All authors contributed to drafting the final manuscript with NK and DGT writing the first draft.

Category of Study: Clinical (observational)

Consent Statement: Prospective written informed parental consent was obtained for each infant prior to enrolment in the study.

Data Sharing: Individual participant data collected during the study, after de-identification, and study protocols and statistical analysis code are available beginning 3 months and ending 23 years following article publication to researchers who provide a methodological sound proposal, with approval by an independent review committee ("learned intermediatry") identified for purpose. Data is available for analysis to achieve aims in the approved proposal. Proposals should be directed to david.tingay@mcri.edu.au; to gain access, data requestors will need to sign a data access or material transfer agreement approved by the Murdoch Children's Research Institute. 
medRxiv preprint doi: https://doi.org/10.1101/2021.01.28.21250723; this version posted February 1, 2021. The copyright holder for this preprint (which was not certified by peer review) is the author/funder, who has granted medRxiv a license to display the preprint in It is made available under a CC-BY-NC-ND 4.0 International license.

\section{Impact Statement}

- In infants without preterm respiratory distress syndrome the time to achieve lung volume stability after a $\mathrm{P}_{\mathrm{AW}}$ change during $\mathrm{HFOV}$ is usually greater than 10 minutes.

- The volume state of the lung at the time of $\mathrm{P}_{\mathrm{AW}}$ change influences the time required to achieve a stable new lung volume; being shorter when the lung is well recruited and longer when the lung is already atelectatic.

- Clinicians should be aware that it may require least 10 minutes before assessing the clinical response to a change in $\mathrm{P}_{\mathrm{Aw}}$ during $\mathrm{HFOV}$ 
medRxiv preprint doi: https://doi.org/10.1101/2021.01.28.21250723; this version posted February 1, 2021. The copyright holder for this preprint (which was not certified by peer review) is the author/funder, who has granted medRxiv a license to display the preprint in It is made available under a CC-BY-NC-ND 4.0 International license

\begin{abstract}
Objectives: Clinicians have little guidance on the time needed before assessing the effect of a mean airway pressure $\left(\mathrm{P}_{\mathrm{AW}}\right)$ change during high-frequency oscillatory ventilation (HFOV). We aimed to determine 1) time to stable lung volume after a $\mathrm{P}_{\mathrm{Aw}}$ change during HFOV and, 2) the relationship between time to volume stability and the volume state of the lung.

Methods: Continuous lung volume measurements (respiratory inductive plethysmography) after 1-2 $\mathrm{cmH}_{2} \mathrm{O} \mathrm{P}_{\mathrm{AW}}$ changes made every 10 minutes during an open lung strategy $(\mathrm{n}=13$ infants) were analysed with a bi-exponential model. Time to stable lung volume (extrapolated to maximum $3600 \mathrm{~s}$ ) was calculated if the model $\mathrm{R}^{2}$ was $>0.6$.
\end{abstract}

Results: $196 \mathrm{P}_{\mathrm{AW}}$ changes were made, with no volume change in 33 (17\%) occurrences. 125 volume signals met modelling criteria for inclusion; median (IQR) $\mathrm{R}^{2} 0.96(0.91,0.98)$. The time to stable lung volume was $1131(718,1959) \mathrm{s}\left(\mathrm{P}_{\mathrm{AW}}\right.$ increases $)$ and $647(439,1309) \mathrm{s}\left(\mathrm{P}_{\mathrm{AW}}\right.$ decreases), with only 17 (14\%) occurring within 10 minutes and time to stability being longer when the lung was atelectatic.

Conclusions: During HFOV, the time to stable lung volume after a $\mathrm{P}_{\mathrm{AW}}$ change is variable, often requires more than 10 minutes and is dependent on the preceding volume state.

Abstract Word Count: 198 words 
medRxiv preprint doi: https://doi.org/10.1101/2021.01.28.21250723; this version posted February 1, 2021. The copyright holder for this preprint (which was not certified by peer review) is the author/funder, who has granted medRxiv a license to display the preprint in It is made available under a CC-BY-NC-ND 4.0 International license .

\section{INTRODUCTION}

The safe and effective delivery of high-frequency oscillatory ventilation (HFOV) depends on achieving an optimal lung volume.(1) During HFOV, the principal determinant of lung volume is the applied mean airway pressure $\left(\mathrm{P}_{\mathrm{AW}}\right) \cdot(2)$ Optimally applied, $\mathrm{P}_{\mathrm{AW}}$ maximises oxygenation(3-5) and lung mechanics(6-8), whilst an inappropriate $\mathrm{P}_{\mathrm{AW}}$ increases adverse events(9) and cardiovascular compromise(10) due to either atelectasis or overdistension. The most recent European guidelines on the management of preterm respiratory distress syndrome (RDS) recommend using an open lung strategy on initiation of HFOV.(11) Open lung strategies involve mapping the quasi-static pressure-volume relationship of the lung using a series of increasing, and then decreasing, $\mathrm{P}_{\mathrm{AW}}$ steps applied over a fixed period of time, with the purpose of identifying the point of optimal oxygenation upon the deflation limb of the pressure volume relationship of the lungs. Usually, peripheral oxygen saturation $\left(\mathrm{SpO}_{2}\right)$ and inspired oxygen fraction $\left(\mathrm{FiO}_{2}\right)$ are used to guide the response. $(3,12,13)$ Critical to the practical application of open lung strategies is an understanding of how rapidly lung volume stabilises after each $\mathrm{P}_{\mathrm{AW}}$ change.

Due to the non-linear mechanical properties of the respiratory system, changes in lung volume follow an exponential plateau pattern after an adjustment in $\mathrm{P}_{\mathrm{Aw}}$.(14-16) The time required to achieve a new steady state lung volume is determined by the time constant of the respiratory system. An understanding of this relationship has important clinical implications for the application of open lung strategies during HFOV. Adequate time must be allowed for achievement of the desired new lung volume with changes in $\mathrm{SpO}_{2}$ reflecting the new volume.(7) In preterm infants with early RDS receiving HFOV as first intention invasive respiratory support, lung volume stabilises within 5 minutes of a $2 \mathrm{cmH}_{2} \mathrm{O} \mathrm{P} \mathrm{PW}_{\mathrm{Aw}}$ change, and varies based on the volume state of the lung; well recruited lungs require less time than partially 
medRxiv preprint doi: https://doi.org/10.1101/2021.01.28.21250723; this version posted February 1, 2021. The copyright holder for this preprint (which was not certified by peer review) is the author/funder, who has granted medRxiv a license to display the preprint in It is made available under a CC-BY-NC-ND 4.0 International license

recruited lungs.(17) Most infants receiving HFOV do not have acute RDS, and many are not preterm.(18) Thus, the poor lung compliance and short time constants associated with acute RDS in preterm infants are unlikely to be translatable to the majority of infants being managed with HFOV as rescue therapy.

We aimed to determine: (1) time to stable lung volume after a $\mathrm{P}_{\mathrm{AW}}$ change during HFOV and, (2) the relationship between time to stable lung volume and the volume state of the lung. These aims are addressed by applying different exponential models of the volumetric behaviour of the lung against time from a series of infants we have previously reported as part of other studies, in which the clinical and volume response to an open lung strategy was measured.(3, 8)

\section{METHODS}

This study was performed at the Neonatal Unit of the Royal Children's Hospital, Melbourne and was approved by the Royal Children's Hospital Human Ethics Committee. Prospective, written, informed parental consent was obtained for each infant prior to enrolment in the study. The dataset used for this study was recorded from infants studied from 2004 to 2006 . A detailed methodology has been published previously. $(3,8)$

\section{Study Population}

Infants receiving HFOV, using the Sensormedics 3100A oscillator (Sensormedics, Yorba Linda, CA), and muscle-relaxants were studied. Infants were not eligible if they had congenital heart disease, a known chromosomal anomaly, refractory hypotension or an inspired oxygen fraction $\left(\mathrm{F}_{\mathrm{IO} 2}\right)$ of greater than 0.9 . 
medRxiv preprint doi: https://doi.org/10.1101/2021.01.28.21250723; this version posted February 1, 2021. The copyright holder for this preprint (which was not certified by peer review) is the author/funder, who has granted medRxiv a license to display the preprint in It is made available under a CC-BY-NC-ND 4.0 International license .

\section{Measurements}

Proximal $\mathrm{P}_{\mathrm{AW}}$ was measured at the airway opening using a Florian respiratory monitor (Acutronic Medical Systems, Zug, Switzerland). Real-time relative changes in lung volume were measured with a low-pass-filtered, DC-coupled respiratory induction plethysmograph (RIP; Respitrace 2007M, Non-invasive Monitoring Systems Inc., North Bay Village, FL) using the technique we have described previously to derive an uncalibrated volume signal in volts, $(3$, 19) following signal thermal stability.(20)

The pressure-volume relationship of the lung was mapped in all infants as part of another study.(3) To summarise this protocol: after achieving an $\mathrm{F}_{\mathrm{IO} 2}$ that maintained a stable $\mathrm{SpO}_{2}$ of 90-94\%, a series of $2 \mathrm{~cm} \mathrm{H}_{2} \mathrm{O} \mathrm{P}_{\mathrm{AW}}$ increases were made every $10 \mathrm{~min}$ (inflation limb) from the $\mathrm{P}_{\mathrm{AW}}$ in clinical use $\left(\mathrm{P}_{\text {initial }}\right)$ until no further improvement in $\mathrm{SpO}_{2}$ was noted over two consecutive $\mathrm{P}_{\mathrm{Aw}}$ increments ( $\mathrm{P}_{\max }$; functional total lung capacity). The deflation limb was then mapped by decreasing $\mathrm{P}_{\mathrm{AW}}$ in $1-2 \mathrm{~cm} \mathrm{H}_{2} \mathrm{O}$ steps every 10 min (deflation limb) until the $\mathrm{P}_{\mathrm{AW}}$ was identified that resulted in $\mathrm{SpO}_{2}<85 \%$ for $5 \mathrm{~min}$ ( $\mathrm{P}_{\text {final }}$; closing pressure of the lung).(3, 4, 21)

\section{Data collection and analysis}

$\mathrm{P}_{\mathrm{AW}}$ and $\mathrm{V}_{\mathrm{RIP}}$ were recorded at $200 \mathrm{~Hz}$, digitized and analysed using custom-built software (LabVIEW ${ }^{\mathrm{TM}}$, National Instruments, Austin, TX). From each RIP recording, the amplitude (VTRIP; Volts) and trough of each tidal oscillation was determined, with the trough voltage defining end-expiratory volume $\left(\mathrm{V}_{\text {LRIP }}\right) . \mathrm{P}_{\mathrm{AW}}$ and $\mathrm{V}_{\text {LRIP }}$ were normalized to the values at $\mathrm{P}_{\max }$ $(100 \%)$ and $\mathrm{P}_{\text {final }}(0 \%) .(3)$ Initially, the time course of the $\mathrm{V}_{\text {LRIP }}$ signal was analysed to determine if any volume change occurred within the $10 \mathrm{~min}$ period (Figure 1). A detectable change was defined as a difference between initial and final $V_{\text {LRIP }}$ voltage of at least $1 / 3$ of the 
medRxiv preprint doi: https://doi.org/10.1101/2021.01.28.21250723; this version posted February 1, 2021. The copyright holder for this preprint (which was not certified by peer review) is the author/funder, who has granted medRxiv a license to display the preprint in It is made available under a CC-BY-NC-ND 4.0 International license .

average oscillatory amplitude ( $\mathrm{V}_{\text {TRIP }}$ value) at that $\mathrm{P}_{\mathrm{AW}}$. This definition was chosen to account for the facts that RIP cannot be reliably calibrated to a known volume during HFOV, has a 3$6 \%$ measurement error, and that $\mathrm{V}_{\text {TRIP }}$ would represent $1-3 \mathrm{~mL} / \mathrm{kg} .(22)$

In the recordings in which $\mathrm{V}_{\text {LRIP }}$ did change, a second-order bi-exponential model was applied to the time course signal:(23)

Inflation Limb: $y=y_{0}+\mathrm{a}\left(1-e^{-t / \tau 1}\right)+\mathrm{b}\left(1-e^{-t / \tau 2}\right)$

Deflation Limb: $y=y_{f}+\mathrm{a} \cdot e^{-t / \tau 1}+\mathrm{b} \cdot e^{-t / \tau 2}$

where $y$ is $\mathrm{V}_{\text {LRIP }}, y_{0}$ is initial $\mathrm{V}_{\text {LRIP }}$ for each time signal recording and $y_{f}$ final $\mathrm{V}_{\text {LRIP }} t$ is time since $\mathrm{P}_{\mathrm{AW}}$ change(s), $a$ and $b$ define the magnitude of volume such that final $\mathrm{V}_{\mathrm{LRIP}}=y_{0}+a+$ $b$, and $\tau_{1}$ and $\tau_{2}$ are time constants.

This model is superior to other non-linear models in a population of spontaneously breathing adults with and without lung disease.(23) Using an extra sum-of-squares F test comparison against a simpler single-order exponential equation,(15) this model is valid in over $90 \%$ of recordings. The time to achieve stable lung volume (defined as $95 \%$ of total $\Delta \mathrm{V}_{\text {LRIP }}$ predicted by the model) was only calculated from those $\mathrm{V}_{\text {LRIP }}$ data in which the model had a goodnessof-fit of $\mathrm{R}^{2} \geq 0.6$. If stability had not occurred within the 10 min recording period, the time extrapolation was permitted to a maximum of $3600 \mathrm{~s}$. Statistical analysis was performed with Prism 9.0 (GraphPad, San Diego, CA, USA) and a p value $<0.05$ was considered significant.

\section{RESULTS}

Thirteen term or near-term infants, corrected for gestational age, were studied. All infants completed the protocol without complications. Their demographic and clinical characteristics 
medRxiv preprint doi: https://doi.org/10.1101/2021.01.28.21250723; this version posted February 1, 2021. The copyright holder for this preprint (which was not certified by peer review) is the author/funder, who has granted medRxiv a license to display the preprint in It is made available under a CC-BY-NC-ND 4.0 International license .

are summarised in Table 1. Seven infants were receiving HFOV to treat meconium aspiration syndrome, four infants had pneumonia and the remaining two infants required HFOV following abdominal surgery. One of these infants was ex-preterm and had evolving chronic lung disease.

A total of $196 \mathrm{P}_{\mathrm{AW}}$ changes were made (54 inflation limb, 142 deflation limb; Supplementary Figure 1). During the deflation series, the $\mathrm{P}_{\mathrm{AW}}$ decrements were of magnitude $2 \mathrm{cmH}_{2} \mathrm{O}(\mathrm{n}=41)$ or $1 \mathrm{cmH}_{2} \mathrm{O}(\mathrm{n}=101)$. The time for $\mathrm{P}_{\mathrm{Aw}}$ to stabilise after a change was $9(2,27) \mathrm{s}$ [median (range)]. $163(83 \%) \mathrm{P}_{\mathrm{AW}}$ changes resulted in a volume change that met the predefined $\Delta \mathrm{V}_{\mathrm{LRIP}}$ criterion for inclusion in the analysis. During the deflation series, a $\Delta \mathrm{V}_{\text {LRIP }}$ satisfying the inclusion criterion was more likely following a $1 \mathrm{cmH}_{2} \mathrm{O}$ change ( $82 \%$ vs $\left.66 \%\right)$, as $1 \mathrm{cmH}_{2} \mathrm{O}$ changes were made around $\mathrm{P}_{\text {final }}$ where volume state was less stable. $(7,8)$ The exponential model could be fitted to the $\mathrm{V}_{\text {LRIP }}$ data with a $\mathrm{R}^{2}>0.60$ for $125 \mathrm{P}_{\mathrm{AW}}$ alterations; median (IQR) $\mathrm{R}^{2} 0.96(0.91,0.98)$.

Figure 1 shows examples of inflation and deflation limb recordings. Only $3(6 \%)$ inflation limb and $14(18 \%)$ deflation limb recordings $(n=125)$ achieved stable $V_{\text {LRIP }}$ within the 10 min recording time ( $\mathrm{p}=0.067$, chi-square test). Stabilisation time was predicted by extrapolation to be within $3600 \mathrm{~s}(60 \mathrm{~min})$ in a further $66(53 \%)$ recordings. Using the model, the median (IQR) time to stable lung volume was $1311(718,1959) \mathrm{s}$ in the inflation limb, and $647(439,1309) \mathrm{s}$ in the deflation limb ( $\mathrm{p}=0.023$, Mann-Whitney test). The time constant of the first phase of the bi-phasic exponential model $\left(\tau_{1}\right)$ was median $8(3,21) \mathrm{s}$.

Figure 2 shows the frequency distribution of all $\Delta \mathrm{V}_{\text {LRIP, }}$ with $56 \%$ (inflation) and $31 \%$ (deflation) of all $\mathrm{P}_{\mathrm{AW}}$ changes requiring at least 30 min until stable $\mathrm{V}_{\text {LRIP }}$ (both $\mathrm{p}<0.0001$; chisquare). Stable $\Delta \mathrm{V}_{\text {LRIP }}$ was more likely to be obtained quickly during the first third of $\mathrm{P}_{\mathrm{AW}}$ 
medRxiv preprint doi: https://doi.org/10.1101/2021.01.28.21250723; this version posted February 1, 2021. The copyright holder for this preprint (which was not certified by peer review) is the author/funder, who has granted medRxiv a license to display the preprint in It is made available under a CC-BY-NC-ND 4.0 International license .

changes, and the last third more likely to require more than 30 min during the deflation limb $\left(\mathrm{p}<0.0001\right.$; chi-square). Figure 3 summarises the time to stable $\Delta \mathrm{V}_{\text {LRIP }}$ within different regions of the pressure-volume relationship.

\section{DISCUSSION}

HFOV is used in the NICU for a diverse range of conditions,(18) and most often as a rescue therapy when conventional modes of mechanical ventilation are not effective. In our population of predominantly term infants receiving rescue HFOV, we found that lung volume had not fully stabilised within 10 min after a $\mathrm{P}_{\mathrm{AW}}$ change in most cases. The time to stability was related to the volume state of the lung, reflecting that volume attainment is a continual and regional process, taking longer in poorly recruited lungs. These findings have implications for the application of open lung strategies during HFOV. Unlike the preterm infant with RDS, clinicians using HFOV in more mature infants will need to allow longer time before interpreting the clinical response to $\mathrm{P}_{\mathrm{AW}}$ changes.

The importance of achieving an optimal lung volume during mechanical ventilation is well understood.(1, 2, 24, 25) During HFOV, $\mathrm{P}_{\mathrm{AW}}$ is the principal determinant of lung volume, but clinicians have few guidelines on setting $\mathrm{P}_{\mathrm{AW}}$. We found that the time to a stable lung volume after a 1-2 $\mathrm{cmH}_{2} \mathrm{O} \mathrm{P}_{\mathrm{Aw}}$ change exhibited high inter- and intrasubject variability. The largest determinant of $\Delta V_{\text {LRIP }}$ was the volume state of the lung, with the time to stable $V_{\text {LRIP }}$ being twice as long during the inflation limb compared to deflation limb. This was expected. During the deflation limb the lung was initially well recruited ('open'), and HFOV occurred on the deflation limb of the pressure-volume relationship. On the deflation limb, alveoli are already recruited, and the lung is in a state of uniform volume. This creates alveolar stability and changes will be smaller and more rapid as long as the volume state remains above the closing 
medRxiv preprint doi: https://doi.org/10.1101/2021.01.28.21250723; this version posted February 1, 2021. The copyright holder for this preprint (which was not certified by peer review) is the author/funder, who has granted medRxiv a license to display the preprint in It is made available under a CC-BY-NC-ND 4.0 International license .

pressure.(8, 26-28) During the inflation limb, recruitment is ongoing with some alveoli atelectatic, others recruiting or recruited, and some potentially overdistended. This heterogeneity of alveolar state, along with poorer lung compliance, increases time constants.(8, 26-28) Our data suggest that clinicians should consider the volume state of the lung when anticipating the clinical response to a $\mathrm{P}_{\mathrm{AW}}$ change.

Only $14 \%$ of $\mathrm{P}_{\mathrm{AW}}$ changes resulted in a stable lung volume within 10 minutes, with 42 changes $(34 \% ; 21$ inflation and 37 deflation limb) predicted to require more than 60 minutes to stabilise. In contrast, a similar study in spontaneously breathing preterm infants receiving an open lung approach to HFOV for acute RDS reported stable lung volumes (measured with real-time continuous electrical impedance tomography; EIT) within approximately 5 min of a $\mathrm{P}_{\mathrm{AW}}$ change.(17) Thome and co-workers reported a large time range of 2 to 25 min (median 9 min) for lung volume stabilisation in preterm infants following $\mathrm{P}_{\mathrm{Aw}}$ changes.(29) In this study lung volume was measured intermittently with the $\mathrm{SF}_{6}$ washout technique.(29) This required temporary conventional ventilation for 1 minute, which may have influenced the findings. Our study involved larger and more mature infants, all of whom were receiving rescue HFOV. None of the infants had primary RDS but rather pathologies analogous to acute respiratory distress syndrome.(30) Absolute lung volume, resistance and compliance is likely to be greater than preterm infants with RDS. With the recent recommendation to use an open lung approach on initiation of HFOV in preterm RDS,(11) clinicians must be aware that the recommended 2-3 minute $\mathrm{P}_{\mathrm{AW}}$ step changes cannot be extrapolated to other neonatal respiratory conditions.(5, 12)

We applied a biphasic exponential model to describe volume change within the lung over time, the first time it has been applied to mechanically ventilated patients. This model has been 
medRxiv preprint doi: https://doi.org/10.1101/2021.01.28.21250723; this version posted February 1, 2021. The copyright holder for this preprint (which was not certified by peer review) is the author/funder, who has granted medRxiv a license to display the preprint in It is made available under a CC-BY-NC-ND 4.0 International license .

previously used to describe forced expiration manoeuvres in adults(23) and passive expiration in newborn lambs.(31) In our population, the biphasic exponential model described the $V_{\text {LRIP }}$ data well, and allowed extrapolation beyond the 10 min $\mathrm{P}_{\mathrm{AW}}$ application period to predict $\Delta \mathrm{V}_{\text {LRIP }}$ behaviour. This model allows for an initial rapid phase of volume change followed by a prolonged slow phase, generating a specific time constant for each. The model was consistent with the raw time- $\mathrm{V}_{\text {LRIP }}$ recordings and is biologically plausible. Open airways and alveoli have a direct connection to large airways and are therefore expected to change volume rapidly after a change in pressure, explaining the very rapid time constants observed in the first phase of the model. However, alveolar opening (recruitment) and closing (de-recruitment) occur more slowly, and are unpredictable,(32) especially in the presence of the noise associated with higher frequency pressure changes within the airways.(33)

Open lung approaches often report an initial increase in lung volume following reductions in initial $\mathrm{P}_{\mathrm{AW}}$ from functional total lung capacity at $\mathrm{P}_{\max } \cdot(3,4,34) \mathrm{We}$, and others, have postulated that this unexpected observation reflects the opening of small airways that were compressed, or release of impeded venous return, at higher $\mathrm{P}_{\mathrm{Aw}} \cdot(3,4,34)$ The bimodal model offers a third possibility that the slow phase of alveolar recruitment is still ongoing during the initial phase of the deflation limb. Whilst the lung is mechanically stable (above closing pressure) on the deflation limb, the initial $V_{\text {LRIP }}$ reductions reflect open lung units rapidly achieving a stable volume, with the slower recruitment of incompletely opened lung units during the previous $\mathrm{P}_{\mathrm{AW}}$ steps, with longer time constants, occurring in the background.

This study is limited to secondary analysis of an existing data set of 13 diverse infants. Although similar in size to previous reports in preterm infants, $(4,17)$ the infants in our study were receiving muscle relaxants. It is likely that spontaneous breathing will shorten the time to 
medRxiv preprint doi: https://doi.org/10.1101/2021.01.28.21250723; this version posted February 1, 2021. The copyright holder for this preprint (which was not certified by peer review) is the author/funder, who has granted medRxiv a license to display the preprint in It is made available under a CC-BY-NC-ND 4.0 International license .

stable volume but also create more uncertainty in the response. Measuring lung volume change in infants during HFOV is difficult. Methods validated in other populations, such as inert gas washout,(29) chest radiograph(35) and computerised tomography,(36) are impractical, intermittent or involve unacceptable radiation. DC-coupled RIP is a well-validated, noninvasive, radiation-free method of continuously monitoring thoracic volume change during HFOV in animals(37) and infants, $(3,8,19,38)$ but is not without some limitations.(3) In particular, RIP cannot differentiate between gas and fluid changes within the chest, unlike newer technologies such as EIT.(39) EIT is also able to define regional volume states.(40) Unfortunately practical EIT systems were not available at the time this study was performed.

\section{Conclusions}

In term and older infants receiving rescue $\mathrm{HFOV}$, the time to a stable lung volume after a $\mathrm{P}_{\mathrm{AW}}$ change is variable, and shorter when the lung is already recruited compared to when it is derecruited. Unlike preterm infants, greater than 10 minutes is often required for lung volume stability. Clinicians should be aware of the importance of the preceding volume state in the lung when assessing the response to a $\mathrm{P}_{\mathrm{AW}}$ change, and the need to allow longer for bedside monitoring to achieve a clinical response.

Acknowledgements: The authors wish to acknowledge Prof Colin J Morley MD, who supervised DGT during the $\mathrm{PhD}$ work that generated the dataset used for this analysis, for his mentoring and advice. 
medRxiv preprint doi: https://doi.org/10.1101/2021.01.28.21250723; this version posted February 1, 2021. The copyright holder for this preprint (which was not certified by peer review) is the author/funder, who has granted medRxiv a license to display the preprint in It is made available under a CC-BY-NC-ND 4.0 International license .

\section{References}

1. Cools F, Askie LM, Offringa M, Asselin JM, Calvert SA, Courtney SE, Dani C, Durand DJ, Gerstmann DR, Henderson-Smart DJ, Marlow N, Peacock JL, Pillow JJ, Soll RF, Thome UH, Truffert P, Schreiber MD, Van Reempts P, Vendettuoli V, Vento G. Elective high-frequency oscillatory versus conventional ventilation in preterm infants: a systematic review and meta-analysis of individual patients' data. Lancet. 375, 2082-2091 (2010).

2. Froese AB, Kinsella JP. High-frequency oscillatory ventilation: lessons from the neonatal/pediatric experience. Crit Care Med. 33, S115-121 (2005).

3. Tingay DG, Mills JF, Morley CJ, Pellicano A, Dargaville PA. The deflation limb of the pressure-volume relationship in infants during high-frequency ventilation. Am J Respir Crit Care Med. 173, 414-420 (2006).

4. Miedema M, de Jongh FH, Frerichs I, van Veenendaal MB, van Kaam AH. Changes in lung volume and ventilation during lung recruitment in high-frequency ventilated preterm infants with respiratory distress syndrome. J Pediatr. 159, 199-205 e192 (2011).

5. De Jaegere A, van Veenendaal MB, Michiels A, van Kaam AH. Lung recruitment using oxygenation during open lung high-frequency ventilation in preterm infants. Am J Respir Crit Care Med. 174, 639-645 (2006).

6. Miedema M, de Jongh FH, Frerichs I, van Veenendaal MB, van Kaam AH. The effect of airway pressure and oscillation amplitude on ventilation in pre-term infants. Eur Respir J. 40, 479-484 (2012).

7. Zannin E, Ventura ML, Dellaca RL, Natile M, Tagliabue P, Perkins EJ, Sourial M, Bhatia R, Dargaville PA, Tingay DG. Optimal mean airway pressure during high-frequency oscillatory ventilation determined by measurement of respiratory system reactance. Pediatr Res. 75, 493-499 (2014). 
medRxiv preprint doi: https://doi.org/10.1101/2021.01.28.21250723; this version posted February 1, 2021. The copyright holder for this preprint (which was not certified by peer review) is the author/funder, who has granted medRxiv a license to display the preprint in It is made available under a CC-BY-NC-ND 4.0 International license .

8. Tingay DG, Mills JF, Morley CJ, Pellicano A, Dargaville PA. Indicators of optimal lung volume during high-frequency oscillatory ventilation in infants. Crit Care Med. 41, 237$244(2013)$.

9. High-frequency oscillatory ventilation compared with conventional mechanical ventilation in the treatment of respiratory failure in preterm infants. The HIFI Study Group. $N$ Engl $J$ Med. 320, 88-93 (1989).

10. Polglase GR, Moss TJ, Nitsos I, Allison BJ, Pillow JJ, Hooper SB. Differential effect of recruitment maneuvres on pulmonary blood flow and oxygenation during HFOV in preterm lambs. J Appl Physiol. 105, 603-610 (2008).

11. Sweet DG, Carnielli V, Greisen G, Hallman M, Ozek E, Te Pas A, Plavka R, Roehr CC, Saugstad OD, Simeoni U, Speer CP, Vento M, Visser GHA, Halliday HL. European Consensus Guidelines on the Management of Respiratory Distress Syndrome - 2019 Update. Neonatology. 115, 432-450 (2019).

12. Rimensberger PC, Beghetti M, Hanquinet S, Berner M. First intention high-frequency oscillation with early lung volume optimization improves pulmonary outcome in very low birth weight infants with respiratory distress syndrome. Pediatrics. 105, 1202-1208 (2000).

13. De Jaegere AP, van der Lee JH, Cante C, van Kaam AH. Early prediction of nasal continuous positive airway pressure failure in preterm infants less than 30 weeks gestation. Acta Paediatr. 101, 374-379 (2012).

14. Otis AB, McKerrow CB, Bartlett RA, Mead J, McIlroy MB, Selver-Stone NJ, Radford EP, Jr. Mechanical factors in distribution of pulmonary ventilation. $J$ Appl Physiol. 8, 427-443 (1956).

15. Stocks J, Sly PD, Tepper RS, Morgan DL. Infant respiratory function testing 1st edn. (Wiley-Liss, New York, 1996). 
medRxiv preprint doi: https://doi.org/10.1101/2021.01.28.21250723; this version posted February 1, 2021. The copyright holder for this preprint (which was not certified by peer review) is the author/funder, who has granted medRxiv a license to display the preprint in It is made available under a CC-BY-NC-ND 4.0 International license .

16. Salazar E, Knowles JH. An Analysis of Pressure-Volume Characteristics of the Lungs. $J$ Appl Physiol. 19, 97-104 (1964).

17. Miedema M, de Jongh FH, Frerichs I, van Veenendaal MB, van Kaam AH. Regional respiratory time constants during lung recruitment in high-frequency oscillatory ventilated preterm infants. Intensive Care Med. 38, 294-299 (2012).

18. Tingay DG, Mills JF, Morley CJ, Pellicano A, Dargaville PA, Australian, New Zealand Neonatal N. Trends in use and outcome of newborn infants treated with high frequency ventilation in Australia and New Zealand, 1996-2003. J Paediatr Child Health. 43, 160$166(2007)$.

19. Tingay DG, Copnell B, Mills JF, Morley CJ, Dargaville PA. Effects of open endotracheal suction on lung volume in infants receiving HFOV. Intensive Care Med. 33, 689-693 (2007).

20. Watson HL, Poole DA, Sackner MA. Accuracy of respiratory inductive plethysmographic cross-sectional areas. J Appl Physiol. 65, 306-308 (1988).

21. Venegas JG, Harris RS, Simon BA. A comprehensive equation for the pulmonary pressurevolume curve. J Appl Physiol. 84, 389-395 (1998).

22. Markhorst DG, Van Gestel JP, van Genderingen HR, Haitsma JJ, Lachmann B, van Vught AJ. Respiratory inductive plethysmography accuracy at varying PEEP levels and degrees of acute lung injury. J Med Eng Technol. 30, 166-175 (2006).

23. Steltner H, Vogel M, Sorichter S, Matthys H, Guttmann J, Timmer J. Analysis of forced expired volume signals using multi-exponential functions. Med Biol Eng Comput. 39, 190$194(2001)$

24. Froese AB. The incremental application of lung-protective high-frequency oscillatory ventilation. Am J Respir Crit Care Med. 166, $786-787$ (2002). 
medRxiv preprint doi: https://doi.org/10.1101/2021.01.28.21250723; this version posted February 1, 2021. The copyright holder for this preprint (which was not certified by peer review) is the author/funder, who has granted medRxiv a license to display the preprint in It is made available under a CC-BY-NC-ND 4.0 International license .

25. Dargaville PA, Tingay DG. Lung protective ventilation in extremely preterm infants. $J$ Paediatr Child Health. 48, 740-746 (2012).

26. Halter JM, Steinberg JM, Schiller HJ, Dasilva M, Gatto LA, Landas S, Nieman GF. Positive end-expiratory pressure after a recruitment maneuver prevents both alveolar collapse and recruitment/derecruitment. Am J Respir Crit Care Med. 167, 1620-1626 (2003).

27. Schiller HJ, Steinberg J, Halter J, McCann U, DaSilva M, Gatto LA, Carney D, Nieman G. Alveolar inflation during generation of a quasi-static pressure/volume curve in the acutely injured lung. Crit Care Med. 31, 1126-1133 (2003).

28. Dargaville PA, Rimensberger PC, Frerichs I. Regional tidal ventilation and compliance during a stepwise vital capacity manoeuvre. Intensive Care Med. 36, 1953-1961 (2010).

29. Thome U, Topfer A, Schaller P, Pohlandt F. Effects of mean airway pressure on lung volume during high-frequency oscillatory ventilation of preterm infants. Am J Respir Crit Care Med. 157, 1213-1218 (1998).

30. De Luca D, van Kaam AH, Tingay DG, Courtney SE, Danhaive O, Carnielli VP, Zimmermann LJ, Kneyber MCJ, Tissieres P, Brierley J, Conti G, Pillow JJ, Rimensberger PC. The Montreux definition of neonatal ARDS: biological and clinical background behind the description of a new entity. Lancet Respir Med. 5, 657-666 (2017).

31. Richardson P, Jarriel S, Hansen TN. Mechanics of the respiratory system during passive exhalation in preterm lambs. Pediatr Res. 26, 425-428 (1989).

32. Suki B, Alencar AM, Tolnai J, Asztalos T, Petak F, Sujeer MK, Patel K, Patel J, Stanley HE, Hantos Z. Size distribution of recruited alveolar volumes in airway reopening. $J$ Appl Physiol. 89, 2030-2040 (2000). 
medRxiv preprint doi: https://doi.org/10.1101/2021.01.28.21250723; this version posted February 1, 2021. The copyright holder for this preprint (which was not certified by peer review) is the author/funder, who has granted medRxiv a license to display the preprint in It is made available under a CC-BY-NC-ND 4.0 International license .

33. Pillow JJ, Hillman N, Moss TJ, Polglase G, Bold G, Beaumont C, Ikegami M, Jobe AH. Bubble continuous positive airway pressure enhances lung volume and gas exchange in preterm lambs. Am J Respir Crit Care Med. 176, 63-69 (2007).

34. Tana M, Polglase GR, Cota F, Tirone C, Aurilia C, Lio A, Ricci C, Romagnoli C, Vento G. Determination of Lung Volume and Hemodynamic Changes During High-Frequency Ventilation Recruitment in Preterm Neonates With Respiratory Distress Syndrome. Crit Care Med. 43, 1685-1691 (2015).

35. Thome U, Topfer A, Schaller P, Pohlandt F. Comparison of lung volume measurements by antero-posterior chest X-ray and the SF6 washout technique in mechanically ventilated infants. Pediatr Pulmonol. 26, 265-272 (1998).

36. Pellicano A, Tingay DG, Mills JF, Fasulakis S, Morley CJ, Dargaville PA. Comparison of four methods of lung volume recruitment during high frequency oscillatory ventilation. Intensive Care Med. 35, 1990-1998 (2009).

37. Brazelton TB, III, Watson KF, Murphy M, Al Khadra E, Thompson JE, Arnold JH. Identification of optimal lung volume during high-frequency oscillatory ventilation using respiratory inductive plethysmography. Crit Care Med. 29, 2349-2359 (2001).

38. Sackner MA, Watson H, Belsito AS, Feinerman D, Suarez M, Gonzalez G, Bizousky F, Krieger B. Calibration of respiratory inductive plethysmograph during natural breathing. $J$ Appl Physiol. 66, 410-420 (1989).

39. Frerichs I, Amato MB, van Kaam AH, Tingay DG, Zhao Z, Grychtol B, Bodenstein M, Gagnon H, Bohm SH, Teschner E, Stenqvist O, Mauri T, Torsani V, Camporota L, Schibler A, Wolf GK, Gommers D, Leonhardt S, Adler A, group Ts. Chest electrical impedance tomography examination, data analysis, terminology, clinical use and recommendations: consensus statement of the TRanslational EIT developmeNt stuDy group. Thorax. 72, 8393 (2017). 
medRxiv preprint doi: https://doi.org/10.1101/2021.01.28.21250723; this version posted February 1, 2021. The copyright holder for this preprint (which was not certified by peer review) is the author/funder, who has granted medRxiv a license to display the preprint in It is made available under a CC-BY-NC-ND 4.0 International license.

40. Miedema M, McCall KE, Perkins EJ, Oakley RB, Pereira-Fantini PM, Rajapaksa AE, Waldmann AD, Tingay DG, van Kaam AH. Lung Recruitment Strategies During High Frequency Oscillatory Ventilation in Preterm Lambs. Front Pediatr. 6, 436 (2018). 
medRxiv preprint doi: https://doi.org/10.1101/2021.01.28.21250723; this version posted February 1, 2021. The copyright holder for this preprint (which was not certified by peer review) is the author/funder, who has granted medRxiv a license to display the preprint in It is made available under a CC-BY-NC-ND 4.0 International license .

\section{FIGURE LEGENDS}

Figure 1. Representative examples of lung volume changes ( $\Delta \mathrm{V}_{\text {LRIP }}$, Arbitrary Units; $\left.A U\right)$ over 10 min following a single adjustment in $\mathrm{P}_{\mathrm{Aw}}$ of $2 \mathrm{cmH}_{2} \mathrm{O}$ during the Inflation (A and $\mathbf{B}$ ) and Deflation (C) limb. Dotted line: $\mathrm{V}_{\text {LRIP }}$, plotted using sequential trough values from the oscillatory waveform (see inset; black dots indicate trough of oscillatory VLRIP time course); solid line: fitted bi-exponential model. In Panel B and $\mathbf{C}$ stable lung volume was achieve before $600 \mathrm{~s} ; 241 \mathrm{~s}\left(\mathrm{R}^{2} 0.78\right)$ and $168 \mathrm{~s}\left(\mathrm{R}^{2} 0.74\right)$, respectively. In panel A, stable lung volume was not achieved by 600 s.

Figure 2. Frequency distribution of time to stable lung volume during the inflation $(\mathbf{A} ; n=54)$ and deflation $(\mathbf{B} ; \mathrm{n}=142)$ limb $\mathrm{P}_{\mathrm{AW}}$ changes. During the deflation limb, $\mathrm{P}_{\mathrm{AW}}$ changes were analysed for the first third (black), middle third (grey) and last third (white) of sequential $\mathrm{P}_{\mathrm{AW}}$ changes from $\mathrm{P}_{\max }$ to $\mathrm{P}_{\text {final. }}$. $\mathrm{V}_{\text {LRIP }}$ recordings that did not meet the criterion for volume change after the $\mathrm{P}_{\mathrm{AW}}$ change are included in the $<1$ minute groups.

Figure 3. Schematic showing the median time to stable lung volume, and representative exponential model of lung volume change over time, for different sections of the normalised pressure-volume relationship of the lung measured during the study.(3) Regions of the pressure-volume relationship are separated by volume into equal thirds of the inflation limb and into equal fifths of the deflation limb. 

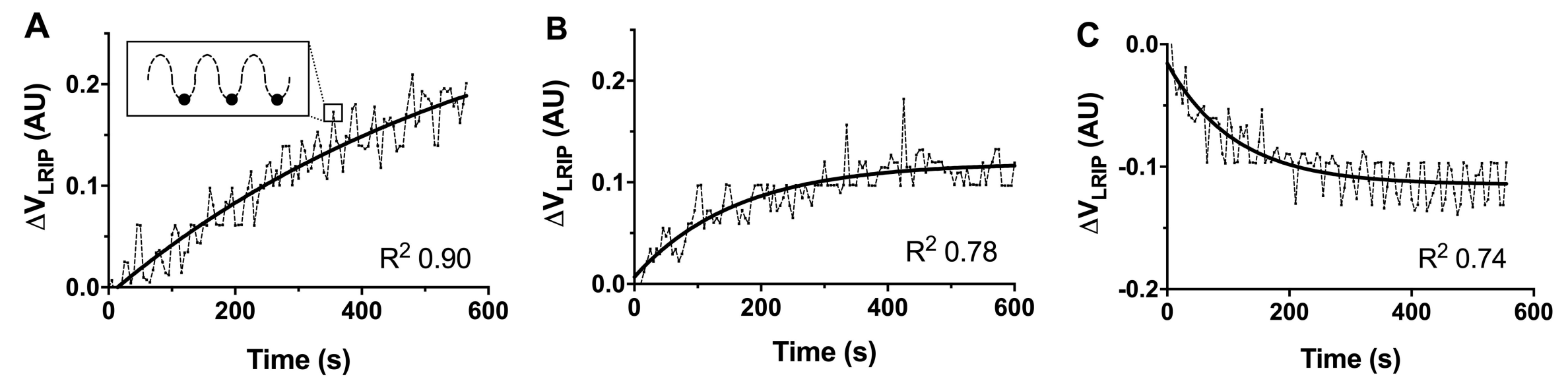


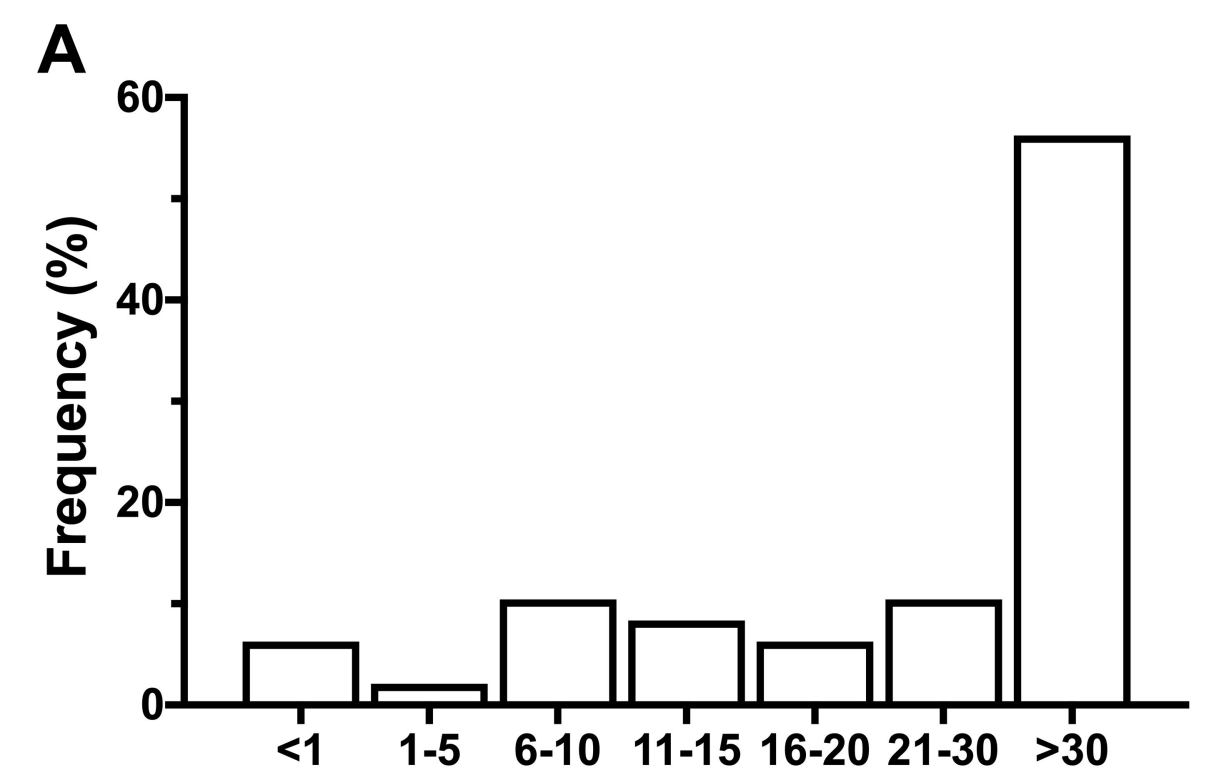

B

Time (min)

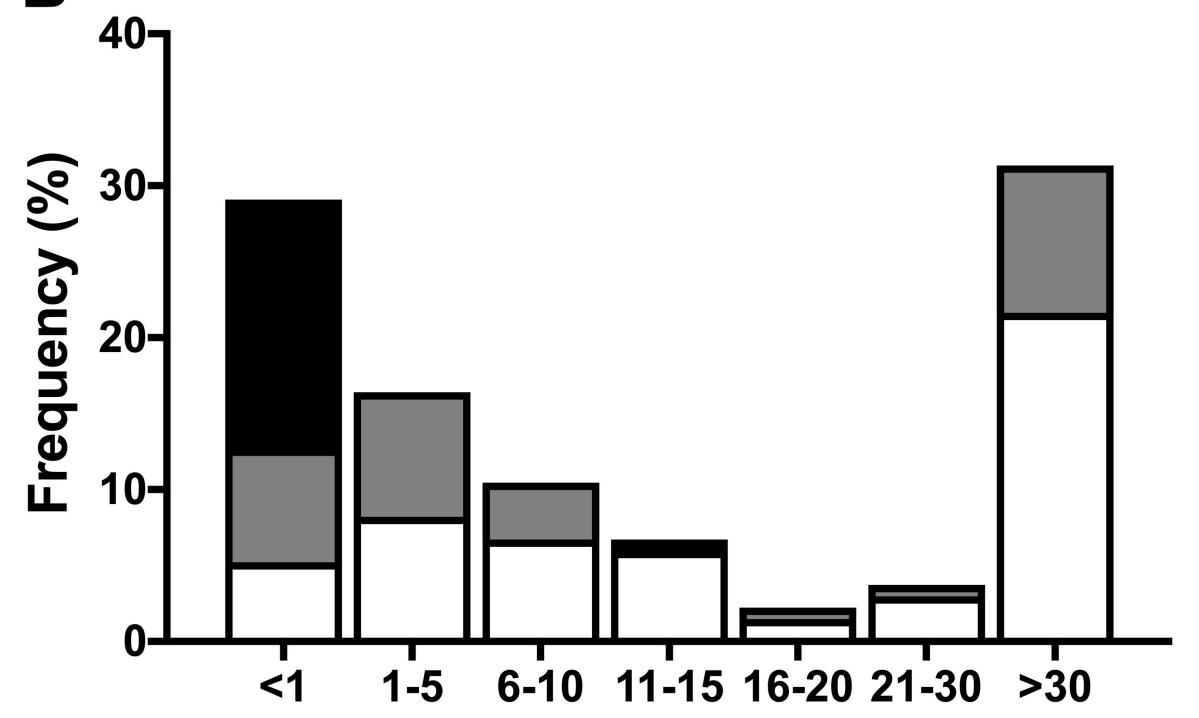
Time (min) 


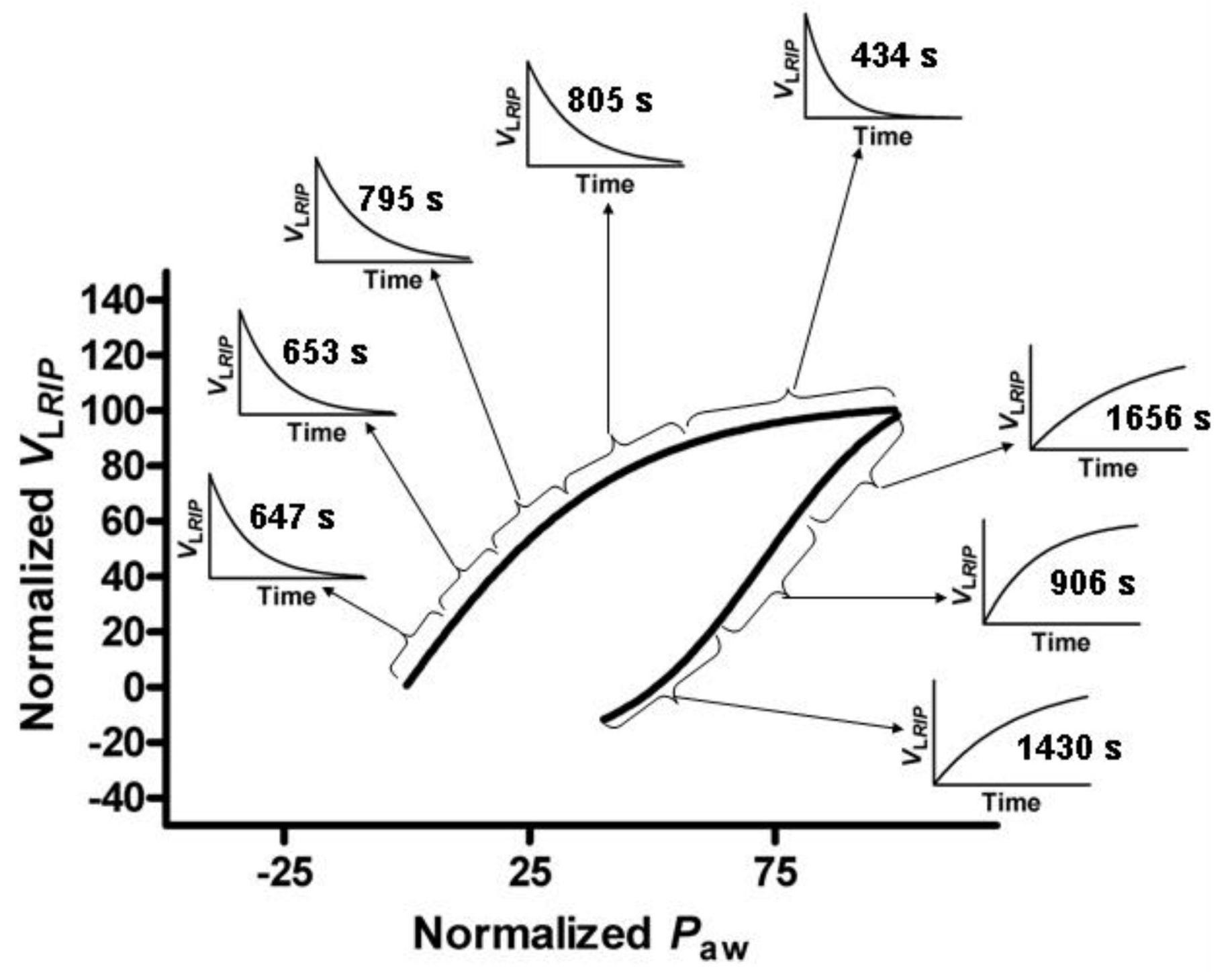


Table 1. Subject characteristics at study commencement $(n=13)$

\begin{tabular}{|c|c|c|c|c|c|c|c|c|c|c|}
\hline \multirow{2}{*}{$\begin{array}{l}\text { Age } \\
\text { (days) }\end{array}$} & \multirow{2}{*}{$\begin{array}{l}\text { Weight } \\
\text { (kg) }\end{array}$} & \multirow{2}{*}{$\begin{array}{l}\text { GA } \\
\text { (weeks) }\end{array}$} & \multirow{2}{*}{$\begin{array}{l}\text { Time on HFOV } \\
\text { (hr) }\end{array}$} & \multicolumn{4}{|c|}{ Initial HFOV settings } & \multicolumn{3}{|c|}{ Gas exchange indices } \\
\hline & & & & $\begin{array}{l}P_{\mathrm{AW}} \\
\left(\mathrm{cm} \mathrm{H_{2 }} \mathrm{O}\right)\end{array}$ & $\begin{array}{l}\Delta P \\
\left(\mathbf{c m ~ H _ { 2 }} \mathbf{O}\right)\end{array}$ & $\begin{array}{l}\text { Fr } \\
(\mathrm{Hz})\end{array}$ & $\mathrm{F}_{\mathrm{IO} 2}$ & $\begin{array}{l}\text { Paco2 } \\
(\mathrm{mmHg})\end{array}$ & $\begin{array}{l}\mathrm{AaDO}_{2} \\
(\mathrm{mmHg})\end{array}$ & OI \\
\hline 2 & 3.4 & 40 & 24 & 14.3 & 33 & 8 & 0.5 & 48 & 197 & 9.6 \\
\hline$(1,42)$ & $(1.1,3.7)$ & $(23,42)$ & $(4,54)$ & $(9.8,17.4)$ & $(21,42)$ & $(6,12)$ & $(0.21,0.9)$ & $(37,100)$ & $(35,526)$ & $(5.5,31.6)$ \\
\hline
\end{tabular}

All data Median and Range.

GA; gestational age, HFOV: high frequency oscillatory ventilation, $\Delta \mathrm{P}$; Amplitude, Fr; Frequency, Paco2; Partial arterial pressure of carbon dioxide, $\mathrm{AaDO}_{2}$; alveolar-arterial oxygen difference, OI; oxygenation index 